\title{
PHOSPHORUS AND ORGANIC MATTER REMOVAL FROM SYNTHETIC WASTEWATER USING ALUM AND ALUMINUM HYDROXIDE
}

\section{D.A. GEORGANTAS \\ H.P. GRIGOROPOULOU*}

\author{
Laboratory of Chemical Process Engineering \\ School of Chemical Engineering \\ National Technical University of Athens
}

Received: $30 / 5 / 2005$

Accepted: 15/2/2006

*to whom all correspondence should be addressed: e-mail: lenag@chemeng.ntua.gr

\begin{abstract}
At present, chemical processes are widely used to remove phosphorus and organic matter from water or wastewater either as the only advanced treatment method or as a pre-treatment stage to biological treatment, and aluminium salts have been traditionally used as coagulants. In the present study removal of orthophosphate or dissolved organic matter with the use of two aluminium sources: alum $\left[\mathrm{Al}_{2}\left(\mathrm{SO}_{3}\right)_{3} \cdot 18 \mathrm{H}_{2} \mathrm{O}\right]$ and aluminium hydroxide $\left[\mathrm{Al}(\mathrm{OH})_{3(\mathrm{~s})}\right]$ is examined for the wastewater treatment process. Amorphous aluminium hydroxide was chosen because it is the hydrolyzed (olated) product of alum and an important adsorbent of inorganic and organic substances in soils since bayerite, gibbsite and boehmite contain a large portion of aluminium hydroxides. Laboratory jar test studies were carried out using either an orthophosphate solution $\left(10 \mathrm{mg} \mathrm{I}^{-1}\right)$ or a tannic acid solution $\left(50 \mathrm{mgC} \mathrm{I}^{-1}\right)$ as simulated wastewater and the effect of parameters such as coagulant dose (up to $15 \mathrm{mg} \mathrm{Al} \mathrm{I}^{-1}$ in the case of alum and up to $90 \mathrm{mg} \mathrm{Al} \mathrm{I}^{-1}$ in the case of $\left.\mathrm{Al}(\mathrm{OH})_{3}\right)$ and $\mathrm{pH}(2-12)$ is investigated. The values of these parameters were based upon measurements on municipal wastewaters from the input of the primary treatment of a wastewater plant in Athens. Orthophosphates have been chosen as a $\mathrm{P}$ surrogate as they are the major portion of the total $P$ found in wastewater and tannic acid solution was used as a surrogate for soluble organic matter. It was proven that alum is much more efficient in phosphorus and tannic acid removal than aluminium hydroxide. The optimal $\mathrm{pH}$ values are 5-6 in both cases, alum and aluminium hydroxide, although alum is efficient in a wider $\mathrm{pH}$ range (4-7) and a mechanism was proposed to interpret these results. In pH values less than 6 the mechanism proposed was chemical bonding between Al species and tannic acid or phosphates creating insoluble complexes while in bigger $\mathrm{pH}$ values (6-8) adsorption on solid $\mathrm{Al}(\mathrm{OH})_{3}$. Freundlich isotherm was proven to fit satisfactorily the experimental data for aluminium hydroxide and orthophosphate at $25^{\circ} \mathrm{C}$ suggesting heterogeneous sorption, with $\mathrm{K}_{\mathrm{F}}$ and $\mathrm{N}$ values 49,1 and 0,19 respectively. The findings of this work may not only contribute to a better understanding of the chemistry of chemical wastewater treatment and therefore to an improvement of the process but also on phosphorus and organics fixation in soils that contain a large portion of aluminium hydroxides.
\end{abstract}

KEYWORDS: alum, aluminium hydroxide, phosphorus, organics, tannic acid, coagulation, adsorption isotherms

\section{INTRODUCTION}

Phosphorus is present in low concentrations in wastewater but its release to a receiving water body is of environmental significance because it is an essential, often limiting nutrient for plants and microorganisms and is therefore a cause of eutrofication.

Apart from $\mathrm{P}$, organic constituents in both souluble and insoluble forms exist in water and wastewater and are associated with unpleasant color and odor, growth substrates for bacteria and can cause health problems [1]. This is the reason why, apart conventional organics 
removal, phosphorus removal is aimed for wastewater plants discharging to sensitive water bodies.

Usually there are two means by which these substances are removed: chemical precipitation and the use of various biological treatment processes. In the case of chemical precipitation, aluminium salts have been traditionally used as coagulants for wastewater treatment [2].

Aluminium sulfate, also known as alum, is the most widely used coagulant but its aqueous chemistry is extremely complex [3]. When added to water, the aluminum ions enter into a series of complicated hydrolysis reactions. These reactions result in large, positively charged molecules having aluminum ions at their centre. The identification of the stable hydrolysis products of $\mathrm{Al}^{3+}$ has been quite difficult not only because of the slow reaction but also because at least one of the stable species in solution is a fairly large polymeric ion difficult to be characterized exactly. Following these reactions, a second type of reaction occurs, called Olation. It involves the bridging of two or more of these large molecules to form even larger, positively charged ions. The hydrolysis of aluminum can be represented as following [3]:

Alum is hydrated and the hydrated aluminum ions are deprotonated. Two deprotonated octahedra can then join to form a dimer, and dimers can join to form a 6member-chain structure by the same deprotonation-dehydration mechanism. These six-member rings may then coalesce further by continued polymerization, resulting in a higher ratio of structural hydroxyl to aluminum. In every molecule, aluminum atoms are bound together by a double hydroxyl bridge:

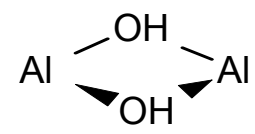

The previous mentioned mechanism is given in Figure 1.

Once these large polymeric aluminum compounds are formed, the magnitude of their high positive charge allows these species to rapidly move toward the colloid, where they are adsorbed onto the negatively charged surface of the turbidity particle. The result of this process is that the electrical charge on the particle is reduced, the suspension is considered to be destabilized and the particles can be brought together. At the same time, an additional process occurs, which assists this process. As the coagulant continues to undergo the hydrolyzation and olation reactions, progressively larger masses of flocculent material are formed. These compounds can become large enough to settle on their own, and tend to trap turbidity particles as they settle. This is commonly referred to as sweep flocculation. Generally, the removal of phosphorus in the wastewater may be attributed to the following mechanisms [4]:

1. Phosphates incorporation to solids in suspension and reduction of these solids during coagulation,

2. Direct adsorption of phosphate ions on the hydrolysis products formed by the addition of alum in wastewater and

3. Formation of phosphate insoluble salts with aluminium. The basic reaction usually taking place in this occasion is: $\mathrm{Al}^{3+}+\mathrm{H}_{n} \mathrm{PO}_{4}{ }^{\mathrm{n}-3} \leftrightarrow \mathrm{AlPO}_{4}+\mathrm{nH}^{+}$.

On the other hand, the removal of humic substances from water or wastewater may be attributed to the following mechanisms [2]:

1. Charge neutralization, when aluminium species interact electrostatically with anionic humic substances to form insoluble charge-neutral products,

2. Entrapment (sweep coagulation),

3. Surface adsorption where insoluble aluminium hydroxide forms, and finally

4. Chemical bond formation between humics and aluminum ion, creating Al-humic complexes.

The prevailing mechanism and the optimum conditions for coagulation in each case depend on different parameters such as initial aluminium or organics concentration, $\mathrm{pH}$, temperature, ionic strength and presence of other ionic species. In the present work jar test studies were carried out using either an orthophosphate or tannic acid solution and the effect of dose and $\mathrm{pH}$ was studied. Amorphous aluminum hydroxide was chosen because although it is the hydrolyzed (olated) product of alum, it has not been widely studied probably due to its 
complex chemistry. Also, besides being known as an effective coagulant, aluminium hydroxide is also an important adsorbent of inorganic and organic substances in soils since bayerite, gibbsite and boehmite, common soil constituents, contain a large portion of aluminium hydroxides [5].

$$
\begin{aligned}
& \mathrm{Al}^{3+}+6 \mathrm{H}_{2} \mathrm{O} \rightarrow \mathrm{Al}\left(\mathrm{H}_{2} \mathrm{O}\right)_{6}{ }^{3+} \\
& \mathrm{Al}\left(\mathrm{H}_{2} \mathrm{O}\right)_{6}{ }^{3+} \Leftrightarrow \mathrm{Al}(\mathrm{OH})\left(\mathrm{OH}_{2}\right)_{5}{ }^{2+}+\mathrm{H}^{+} \text {where } \mathrm{Al}\left(\mathrm{H}_{2} \mathrm{O}\right)_{6}{ }^{3+}=
\end{aligned}
$$

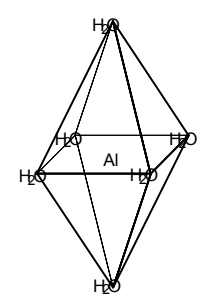

$$
2 \mathrm{Al}(\mathrm{OH})\left(\mathrm{OH}_{2}\right)_{5}{ }^{2+} \Leftrightarrow \mathrm{Al}_{2}(\mathrm{OH})_{2}\left(\mathrm{OH}_{2}\right)_{8}{ }^{4+}+2 \mathrm{H}_{2} \mathrm{O}
$$

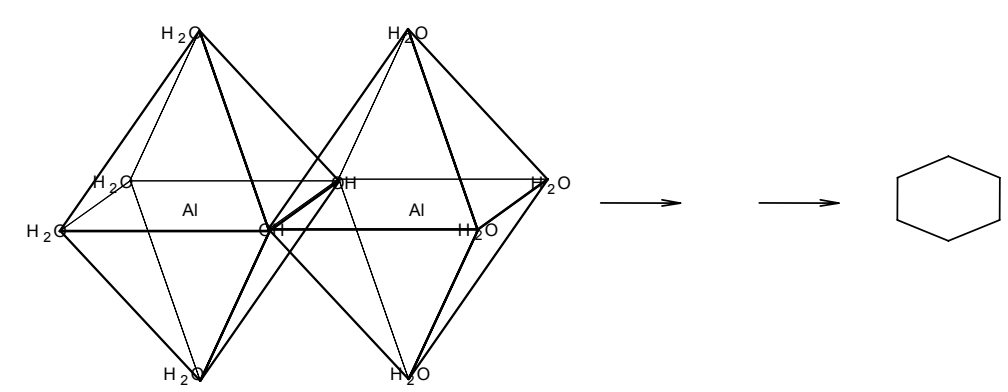

$$
\mathrm{Al}_{2}(\mathrm{OH})_{2}\left(\mathrm{OH}_{2}\right)_{8}{ }^{4+} \quad \rightarrow \ldots \ldots . . \quad \rightarrow \quad \mathrm{Al}_{6}(\mathrm{OH})_{12}{ }^{6+} \bullet 12 \mathrm{H}_{2} \mathrm{O}
$$

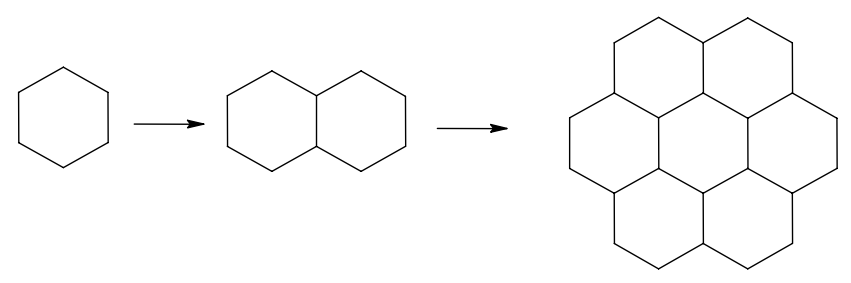

$$
\mathrm{Al}_{6}(\mathrm{OH})_{12}{ }^{6+} \cdot 12 \mathrm{H}_{2} \mathrm{O} \rightarrow \mathrm{Al}_{10}(\mathrm{OH})_{22}{ }^{8+} \cdot 16 \mathrm{H}_{2} \mathrm{O} \rightarrow \mathrm{Al}_{24}(\mathrm{OH})_{60}{ }^{12+} \cdot 24 \mathrm{H}_{2} \mathrm{O}
$$

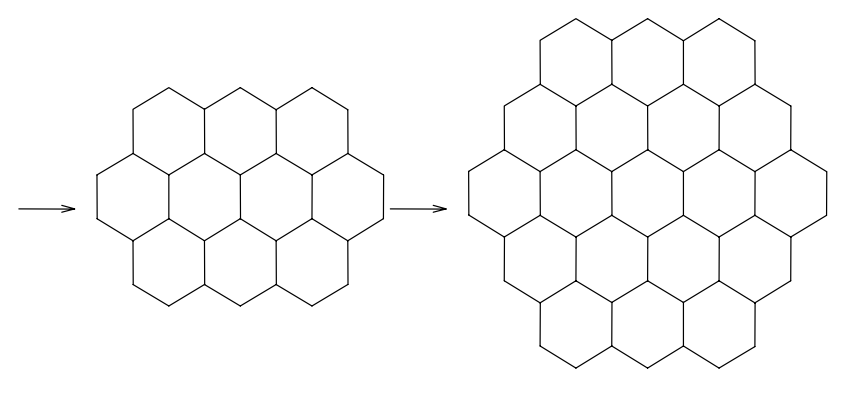

$$
\mathrm{Al}_{32}(\mathrm{OH})_{82}{ }^{14+} \cdot 28 \mathrm{H}_{2} \mathrm{O} \rightarrow \mathrm{Al}_{54}(\mathrm{OH})_{144}{ }^{18+} \bullet 36 \mathrm{H}_{2} \mathrm{O}
$$

Figure 1. Proposed mechanism for alum hydrolysis and polymerisation in water

Orthophosphates have been chosen as a $\mathrm{P}$ surrogate as they are the major portion of the total $P$ found in wastewater [6]. The experimental investigation was repeated using a tannic acid solution as a surrogate for soluble organic matter. Tannic acid is a water soluble hydrophilic acid with a molar mass of 1701,23 . It consists of saccharide, aromatic, -COO- and phenolic hydroxyl groups and has been a modelling agent in the research on dissolved organic matter [7]. Its chemical structure is represented in Figure 2. 
In order to investigate the sorption isotherm in the case of aluminum hydroxide, two equilibrium models were analyzed: The Lagmuir and Freundlich isotherms [8]. The Lagmuir sorption isotherm is perhaps the best-known describing sorption. The surface sites are considered homogeneous with no lateral interactions among binding sites and is expressed by the following equation:

$\mathrm{q}_{\mathrm{e}}=\frac{\mathrm{q}_{\mathrm{m}} \cdot \mathrm{K}_{\mathrm{a}} \cdot \mathrm{C}_{\mathrm{e}}}{1+\mathrm{K}_{\mathrm{a}} \cdot \mathrm{C}_{\mathrm{e}}}$

The Freundlich isotherm is the earliest known relationship describing sorption. It involves heterogeneous sorption and is expressed by the following equation:

$\mathrm{q}_{\mathrm{e}}=\mathrm{K}_{\mathrm{F}} \cdot \mathrm{C}_{\mathrm{e}}^{\mathrm{N}}$ (2) where:

$\mathrm{q}_{\mathrm{e}}$ the amount of phosphate sorbed per unit weight of sorbent at equilibrium ( $\mathrm{mg} \mathrm{g}^{-1}$ )

$\mathrm{q}_{\mathrm{m}}$ constant which is equal to the maximum value of $\mathrm{q}_{\mathrm{e}}\left(\mathrm{mg} \mathrm{g}^{-1}\right)$

$\mathrm{C}_{\mathrm{e}}$ equilibrium concentration $\left(\mathrm{mg} \mathrm{l}^{-1}\right)$

$\mathrm{K}_{\mathrm{F}}$, N Freundlich constants

The purpose of the present study was to contribute to a better understanding of the interaction between orthophosphate and 2 aluminum sources: alum and aluminum hydroxide $\left[\mathrm{Al}(\mathrm{OH})_{3(\mathrm{~s})}\right]$ in the wastewater treatment process. The findings of this work may contribute to the understanding of the adsorption chemistry of phosphates and humics and may not only be used on the improvement of chemical phosphorus and organic removal but also in the phosphorus fixation on soils for agricultural purposes.

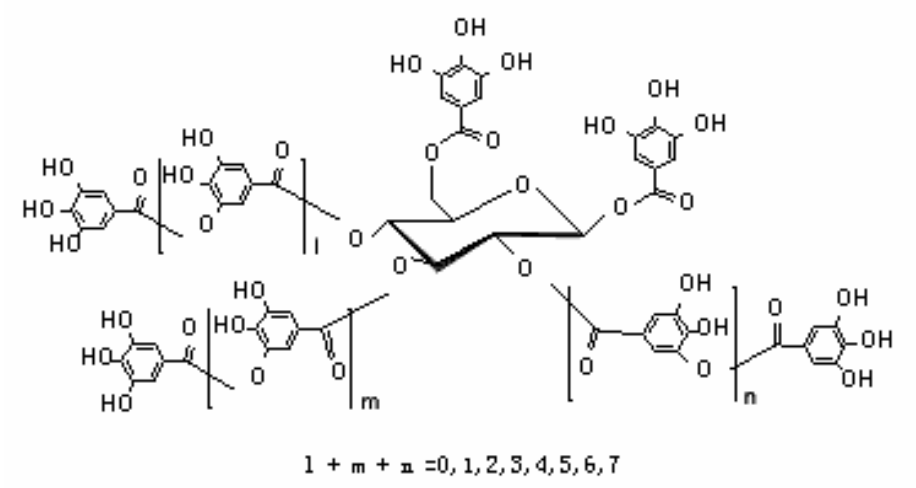

Figure 2. Structure of tannic acid molecule [9]

\section{MATERIALS AND METHODS}

\subsection{Materials, apparatus and experimental procedure}

The synthetic wastewater consisted either of $10 \mathrm{mgP} \mathrm{I}^{-1}$ as $\mathrm{KH}_{2} \mathrm{PO}_{4}$ (Ferak Berlin) or $50 \mathrm{mgC}$ $\mathrm{I}^{-1}$ as tannic acid (Merck). Aluminum hydroxide was prepared and characterized as reported by $\mathrm{Hsu}$ and Rennie [10]. Also $\mathrm{Al}_{2}\left(\mathrm{SO}_{4}\right) \cdot 18 \mathrm{H}_{2} \mathrm{O}, \mathrm{NaOH}, \mathrm{HCl}$ (all by Merck) and de-ionized water were used in this study.

All the experiments were carried out using a jar-test apparatus by G.Vittadini. $250 \mathrm{ml}$ of wastewater were stirred rapidly at $90 \mathrm{rpm}$ for $3 \mathrm{~min}$ and then at $40 \mathrm{rpm}$ for $30 \mathrm{~min}$. The measurements were performed after $30 \mathrm{~min}$ of settling and the $\mathrm{pH}$ of the solution was set rapidly and kept to 6 or adjusted to the desired value by adding proper amounts of $\mathrm{NaOH}$ or $\mathrm{HCl}$ when needed. At the end of each experiment, samples were removed and filtered through a $0.45-\mu \mathrm{m}$ membrane before being analyzed for TOC or orthophosphate.

\subsection{Analytical procedures [11]}

Orthophosphate concentration was measured by the vanadate-molybdate method using a Camspec M302 spectophotometer at 470nm [11, method 4-144]. Total carbon concentration was measured by using a Shimadzu TOC- $\mathrm{V}_{\mathrm{CSH}}$ analyzer. $\mathrm{pH}$ was measured by a WTW 538 pHmeter. Aluminum was measured by atomic spectrophotometry using a Perkin-Elmer 
analyst, type 460 and according to the manufacturer's manual. Aluminium hydroxide was digested using nitric acid, filtered, diluted and measured [11, method 3-8]. X-ray diffraction of $\mathrm{Al}(\mathrm{OH})_{3}$ was performed using a Siemens D5000 diffractometer with CuKa radiation operating at $40 \mathrm{kV}$ and $30 \mathrm{~mA}$ : the sample was filtered through a $0.45 \mu \mathrm{m}$ membrane, washed with deionized water, vacuum dried for one day, grated into a fine powder and then measured.

\section{RESULTS AND DISCUSSION}

\subsection{Preparation and characterization of aluminum hydroxide}

Amorphous aluminum hydroxide suspension was prepared by dissolving $92,6 \mathrm{~g}$ of aluminum sulfate hexadecahydrate $\left(\mathrm{Al}_{2}\left(\mathrm{SO}_{4}\right)_{3} 18 \mathrm{H}_{2} \mathrm{O}\right)$ in $700 \mathrm{ml}$ of deionized water [10]. Sodium hydroxide $(\mathrm{NaOH}) 1 \mathrm{~N}$ was then added by a peristaltic pump at a rate of $3 \mathrm{ml} \mathrm{min}^{-1}$. The whole system was stirred during the addition of the base by a magnetic stirrer and the $\mathrm{pH}$ was monitored by a $\mathrm{pH}$ electrode. When the $\mathrm{pH}$ reached 4,5-5 a sharp rise of the viscosity was noticed accompanied by a sharp increase of the $\mathrm{pH}$ as seen in Figure 3.

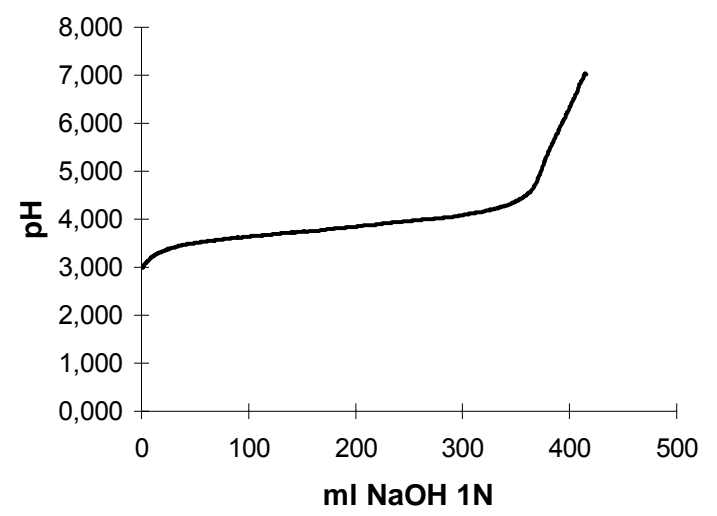

Figure 3. Potentiometric titration of alum using $\mathrm{NaOH} 1 \mathrm{~N}\left(\mathrm{~T}=25^{\circ} \mathrm{C}\right)$

At the beginning of the curve and until $\mathrm{pH} \approx 4$ the added hydroxide did not increase significantly the $\mathrm{pH}$ value indicating that the added hydroxide ions were immediately bound to $\mathrm{Al}$ ions. At about $\mathrm{pH}=5$ a break point of the curve was noticed and a sharp increase in the $\mathrm{pH}$ of the solution was noticed indicating that the hydroxide ions were not bound to hydroxy aluminum molecules but remained in solution. When $\mathrm{pH}$ reached 7 the addition of the base was stopped and the system was maintained at this $\mathrm{pH}$ while kept strirring for $1 \mathrm{~h}$. The gel was filtrated and washed several times with water in order to remove excess sulfate ions, then adjusted to a volume of 11 with deionised water and stored in a tightly capped $1 /$ bottle. XRD measurements were made and the gel was proved to be amorphous. Also AAS was used to measure total Al concentration in the gel and the filtrate and it was proved that Al was present only in the solid phase of the gel and not in the filtrate.

\subsection{Comparison between aluminium sources}

In Figures 4 and 5 , remaining phosphorus and total carbon concentration and the ratio mmol $\mathrm{P}$ or $\mathrm{C}$ sorbed $\mathrm{mmol}^{-1}$ of $\mathrm{Al}$ added versus initial $\mathrm{Al}$ concentration are presented for both aluminum sources. In all cases it can be clearly seen that alum is much more efficient than aluminum hydroxide for the same doses of $\mathrm{Al}$ applied. In Figure $4 \mathrm{~b}$ for doses of alum up to about $5 \mathrm{mg} \mathrm{I}^{-1}$ the ratio mmol Psorbed $\mathrm{mmol}^{-1}$ of $\mathrm{Al}$ added is near 1 (stoichiometric removal) and therefore implying that $\mathrm{P}$ removal is due to the formation of aluminum phosphate. For higher alum doses the ratio decreases probably due to the formation of aluminum hydroxide and therefore the removal of $\mathrm{P}$ can be attributed to the other mechanisms cited in Introduction. According to Hsu and Rennie [10], orthophosphate removal in the case of $\mathrm{Al}(\mathrm{OH})_{3}$ should be followed by a displacement of $\mathrm{OH}^{-}$from the surface and the phosphate would be adsorbed on the surface if the attraction between $\mathrm{P}$ and $\mathrm{Al}(\mathrm{OH})_{3}$ is strong enough to remove the surface $\mathrm{OH}^{-}$. However the total surface $\mathrm{OH}^{-}$available for adsorption depends on phosphate in solution: when phosphate concentration in the solution is very high, the high attraction may break $\mathrm{Al}(\mathrm{OH})_{3}$ polymer in smaller particles producing additional surface for 
adsorption. In our case, the initial $\mathrm{P}$ concentration is constant and therefore increasing $\mathrm{Al}(\mathrm{OH})_{3}$ dose both initial ratio of mmoleP $\mathrm{mmol}^{-1} \mathrm{Al}$ and aluminium hydroxide-phosphate attraction decrease resulting in less surface for adsorption. In the case of tannic acid and alum, as shown in Figure $5 \mathrm{a}$, the removal was maximal above a coagulant dose of $8 \mathrm{mg} \mathrm{l}^{-1} \mathrm{Al}$ which corresponds to $90 \%$ removal and did not significantly deteriorate above this dose (up to $40 \mathrm{mg} \mathrm{l}^{-1} \mathrm{Al}$ ). Also as seen in Figure $5 \mathrm{~b}$ for concentrations up to $5 \mathrm{mg} \mathrm{Al} \mathrm{I}^{-1}$ the ratio mmol Csorbed $\mathrm{mmol}^{-1} \mathrm{Al}$ increases while in higher doses this ratio decreases. As mentioned above, at low alum doses or low $\mathrm{pH}, \mathrm{Al}^{3+}$ prevails and tannic acid removal is attributed to a chemical bond between tannic and aluminum ion, creating Al-tannate complexes. These complexes may be water-soluble or water-insoluble depending on their molecular size [12]. As the alum dose is increased, aluminum tannate may aggregate and form precipitates which can trap either other complexes or free tannic acid molecules. This mechanism can interpret the increase of the ratio mmolCsorbed / mmol Al up to an alum dose of about $5 \mathrm{mg} \mathrm{Al} \mathrm{I}^{-1}$ of solution. From this alum dose and after, when insoluble amorphous aluminum hydroxide begins to form, tannic acid can be removed by entrapment (sweep coagulation) or surface adsorption. It can be seen that in the case of aluminum hydroxide the ratio is almost constant and much lower than in the case of alum (about 0,8 ).
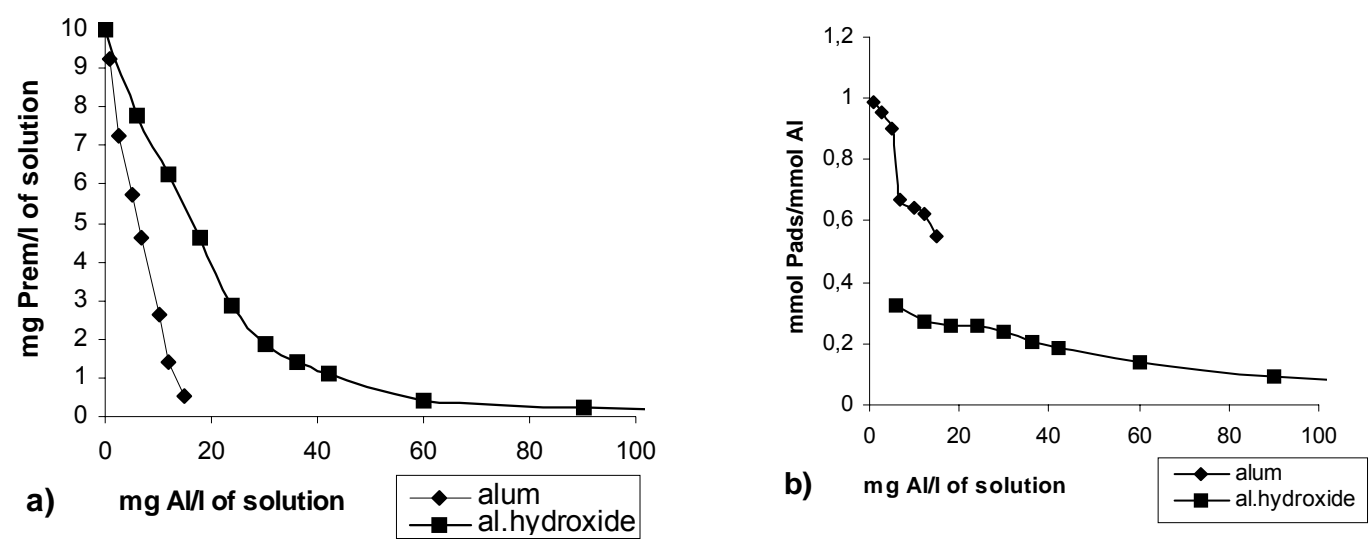

Figure $4 a, b$. Comparison between alum and aluminum hydroxide regarding their efficiency to remove orthophosphate in solution $\left(\mathrm{T}=25^{\circ} \mathrm{C}, \mathrm{pH}=6,10 \mathrm{mg} \mathrm{Pl}^{-1}\right)$
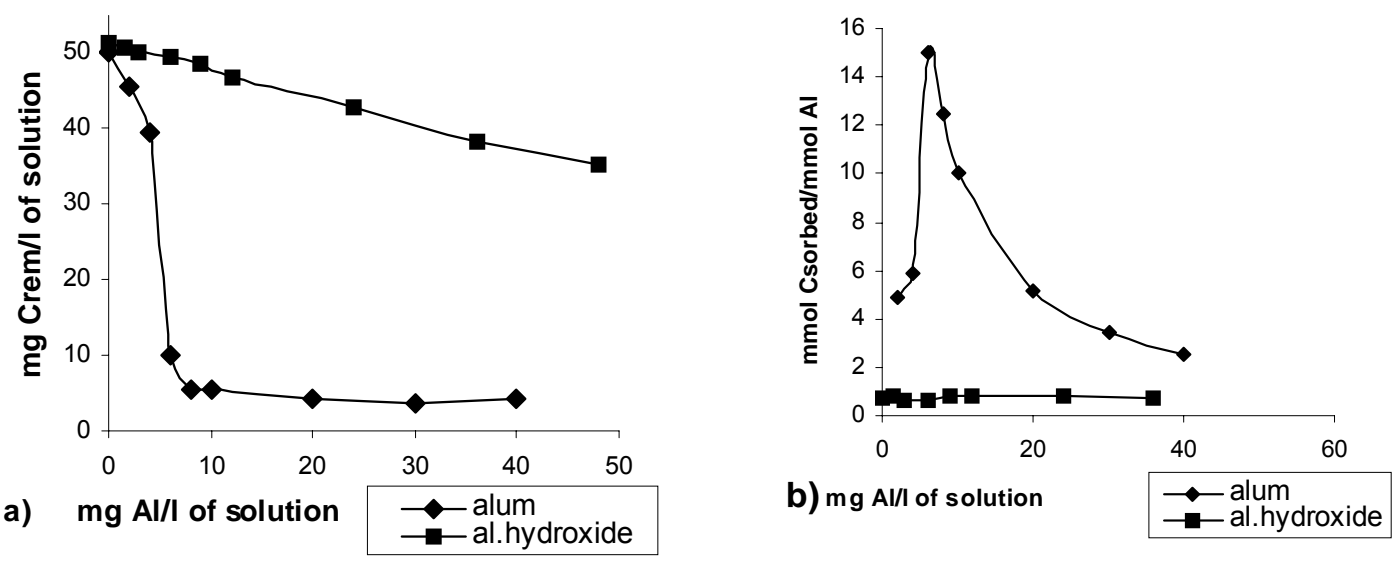

Figure $5 a, b$. Comparison between alum and aluminum hydroxide regarding their efficiency to remove tannic acid in solution $\left(\mathrm{T}=25^{\circ} \mathrm{C}, \mathrm{pH}=6,50 \mathrm{mg} \mathrm{C} \mathrm{I}^{-1}\right)$ 


\subsection{Effect of $\mathrm{pH}$}

The $\mathrm{pH}$ range in which coagulation occurs may be the most important factor for proper coagulation [13]. In Figure 6a,b the remaining $\mathrm{P}$ (orthophosphate) and $\mathrm{C}$ (tannic acid) versus $\mathrm{pH}$ are presented.

It can be seen that maximum orthophosphate and organic removal is achieved at $\mathrm{pH}$ values of 5-6 in both cases, although alum is efficient in a wider $\mathrm{pH}$ range (4-7). The results can be interpreted as follows:

In the case of orthophosphate, below a $\mathrm{pH}$ range of 5.5 the hydration/olation reactions shown in Figure 1 do not proceed. Additionally, the formation of insoluble $\mathrm{AlPO}_{4}$ according to the reaction

$$
\mathrm{Al}^{3+}+\mathrm{H}_{\mathrm{n}} \mathrm{PO}_{4}{ }^{\mathrm{n}-3} \leftrightarrow \mathrm{AlPO}_{4}+\mathrm{nH}^{+}
$$

is not favoured as $\mathrm{AlPO}_{4}$ is soluble below $\mathrm{pH}=6$ [13]. On the other hand, when water $\mathrm{pH}$ is above 8 after the addition of the alum, aluminium ions again become soluble $\left(\mathrm{Al}(\mathrm{OH})_{4}{ }^{-}\right)$, and the efficiency of coagulation is consequently decreased.
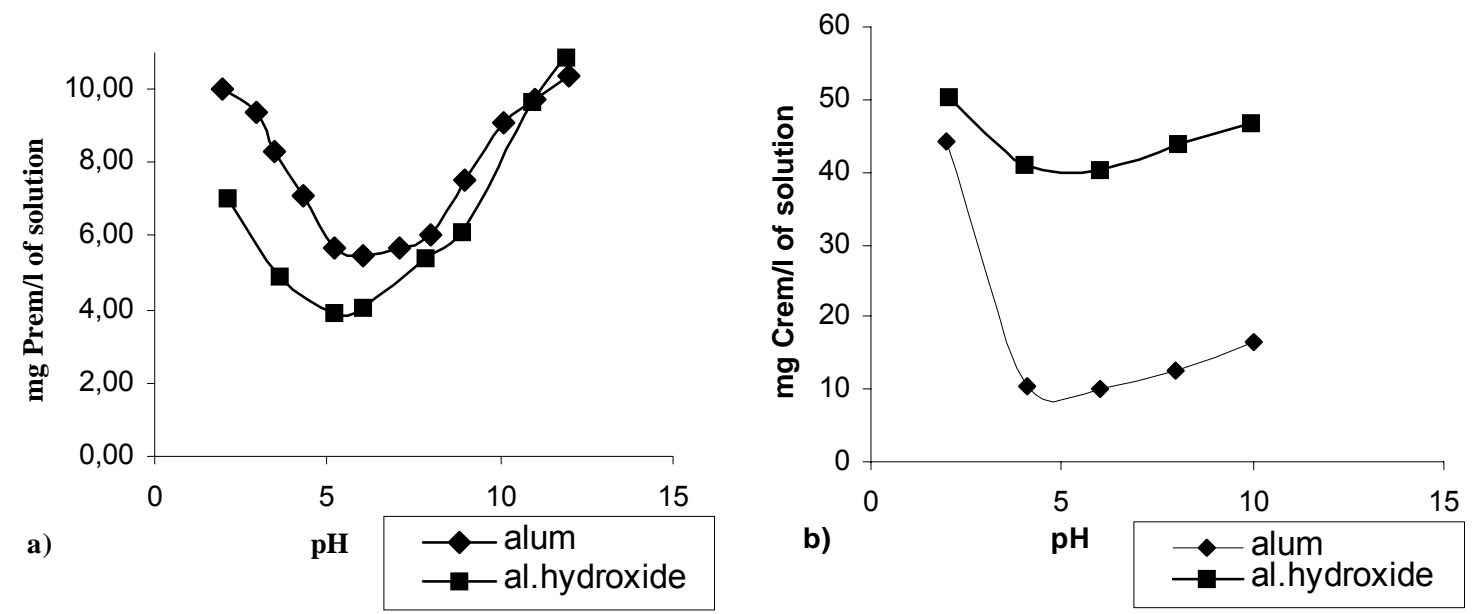

Figures $6 a, b$. Comparison between alum and aluminum hydroxide regarding their efficiency to remove orthophosphate and tannic acid respectively in solution $\left(5 \mathrm{mg} \mathrm{Al} \mathrm{I}^{-1}\right.$ in the case of alum, $18 \mathrm{mg} \mathrm{Al}^{-1}$ in the case of $\left.\mathrm{Al}(\mathrm{OH})_{3}, \mathrm{~T}=25^{\circ} \mathrm{C}\right)$

In the case of tannic acid the mechanism of the removal is quite complex but the results can be interpreted as follows [14]:

As mentioned before, tannic acid consists of -COO- and phenolic hydroxyl groups. In lower values of $\mathrm{pH}$ these groups are protonated according to the reactions:

$$
\begin{gathered}
-\mathrm{COO}^{-}+\mathrm{H}^{+} \leftrightarrow-\mathrm{COOH} \\
\text { Phenolic- } \mathrm{O}^{-} \leftrightarrow \text { Phenolic-OH }
\end{gathered}
$$

This causes tannic acid macromolecule to have few anionic centers and the following structure:

On the other hand in these low $\mathrm{pH}$ values $\mathrm{Al}$ monomers are prevailing. As the $\mathrm{pH}$ is raised to about 4 , more anionic sites are generated by deprotonation of acidic carboxyl groups and at the same time the molecules unwind and become more linear because of the repulsion of the increasing negative sites. Therefore, each aluminum ion can interact with more than one tannic acid molecules or multiple connections between one tannic acid molecule and one aluminum ion can be established. This results to the production of insoluble complexes consisting of organic molecules linked together by aluminum bridges. As the $\mathrm{pH}$ is raised 
even further $(>5,5), \mathrm{Al}^{3+}$ is hydroxylated producing $\mathrm{Al}-\mathrm{OH}$ species and as a result, new mixeddonor complexes are formed, where the bridges are now -Al-OH- groups. Furthermore, at about $\mathrm{pH}=7$ solid $\mathrm{Al}(\mathrm{OH})_{3}$ is also produced offering new nucleation sites for flocculation and tannic acid adsorption on its surface. Therefore the $\mathrm{Al}(\mathrm{OH})_{3}$ and tannic acid interaction mechanism is neither charge-neutralization nor complex formation but adsorption on surface sites. This hydrolyzed product however has less positive charge and therefore Al salt is less effective. At even bigger $\mathrm{pH}$ values (>8), Al species are mostly in the soluble form of $\mathrm{Al}(\mathrm{OH})_{4}{ }^{-}$ being negatively charged and cannot remove tannic acid successfully.

In the case of $\mathrm{Al}(\mathrm{OH})_{3}$, the following reactions occur [15]:

$$
\begin{gathered}
\mathrm{Al}(\mathrm{OH})_{3}+3 \mathrm{H}^{+} \leftrightarrow \mathrm{Al}^{3+}+3 \mathrm{H}_{2} \mathrm{O} \\
\mathrm{Al}(\mathrm{OH})_{3}+\mathrm{OH}^{-} \leftrightarrow \mathrm{Al}(\mathrm{OH})_{4}^{-}
\end{gathered}
$$

and therefore at low or high $\mathrm{pH}$ values aluminum hydroxide interacts with tannic acid and orthophosphate like alum while in the range of 5-6 acts by the adsorption mechanism mentioned above and this is probably the cause for the similarity of the experimental results in Figure 6.

The mechanism of organics removal in the case of aluminum hydroxide and alum is presented in Figure 7. It can be noted that this mechanism is extremely complex but it can somehow interpret why better results are accomplished in $\mathrm{pH}$ values between 6 and 8 .
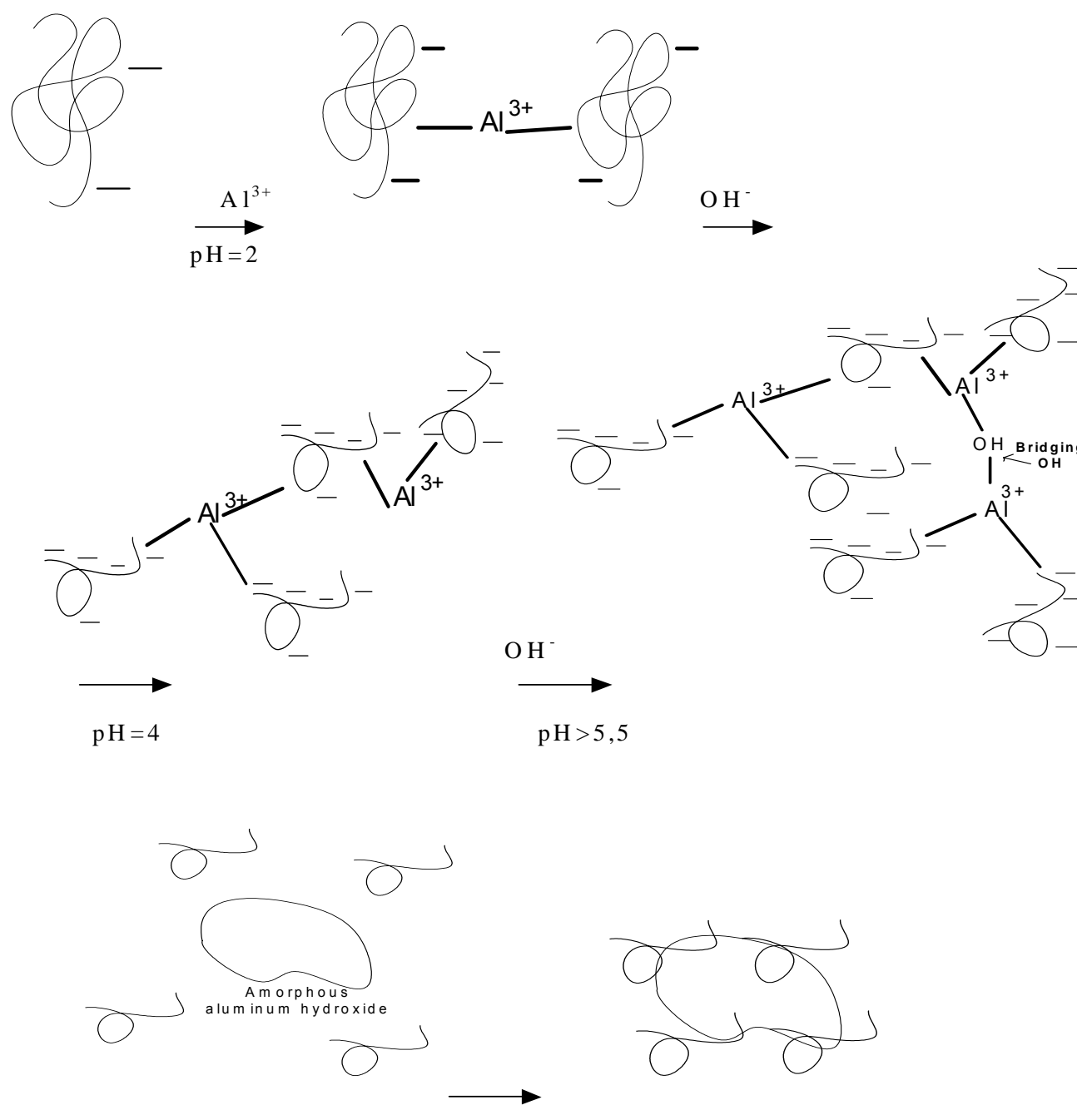

Figure 7. Proposed mechanism of interaction of alum and tannic acid at various $\mathrm{pH}$ values 


\subsection{Adsorption isotherms of aluminium hydroxide}

Equations (1) and (2) are fitted to the experimental data for orthophosphate removal. As it can be clearly seen from Figure 8 , the Freundlich isotherm describes equilibrium satisfactorily and the constants are: $K_{F}=49,1 \mathrm{~N}=0,19$.

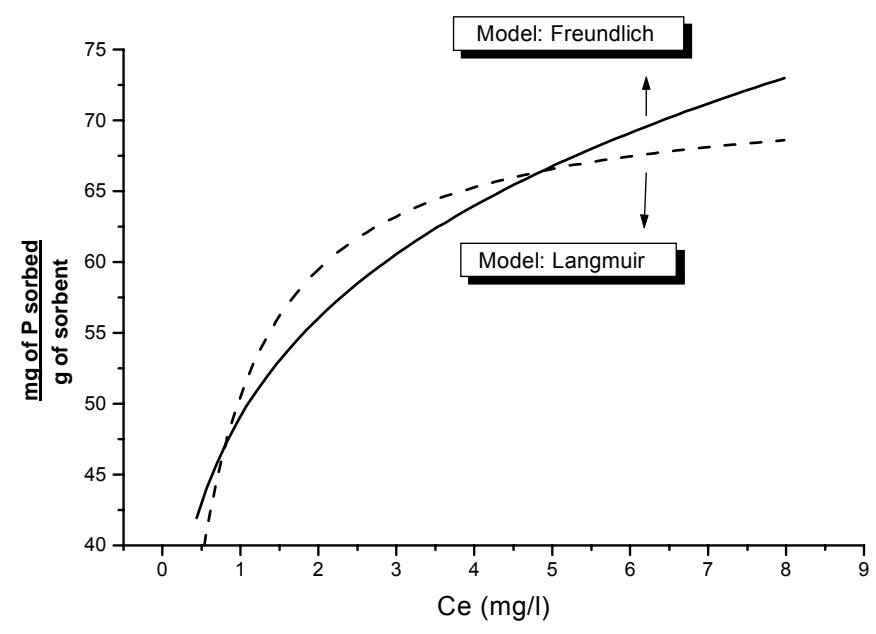

Figure 8. Sorption isotherm for aluminum hydroxide and synthetic wastewater containing orthophosphate for $25^{\circ} \mathrm{C}(\mathrm{pH}=6)$

\section{CONCLUSIONS}

The following conclusions may be drawn from the study carried out:

- Alum is much more efficient in phosphorus and tannic acid removal than $\mathrm{Al}(\mathrm{OH})_{3}$

- Maximum orthophosphate and organic removal is achieved at $\mathrm{pH}$ values 5-6 in both cases, alum and aluminum hydroxide, although alum is efficient in a wider $\mathrm{pH}$ range (4-7) and a mechanism was proposed to interpret these results.

- Freundlich isotherm was proved to fit satisfactorily the equilibrium experimental data for aluminum hydroxide and orthophosphate ions.

\section{REFERENCES}

1. Benschoten J.E., Edzwald J.K.,(1990) Chemical aspects of coagulation using aluminum salts II.Coagulation of fulvic acid using alum and polyaluminum chloride, Water Research 24(12) 1527-1535.

2. Rebhum M., Lurie M. (1993) Control of Organic Matter by Coagulation and Floc Separation, Wat. Sci. Tech. 27 (11), 1-20.

3. Hem S., White J, Nail S. (1976) Structure of Aluminum Hydroxide Gel I: Initial precipitate. Journal of Pharm. Sciences 65 (8), 1188-1191.

4. Aguilar M.I., Saez J.,Llorens M.,Soler A.,Ortuno J.F. (2002) Water Research 36(11), 2910-2919.

5. Hiemstra T., Van-Riemsdijk W.H. 1999) Surface Structural Ion Adsorption Modeling of Competitive Binding of Oxyanions by Metal (Hydr)oxides, Journal of Colloid and Interface Science, 210 (1),182-193.

6. Omoike A.,Vanloon G.,(1999),Removal of phosphorus and organic matter removal by alum during wastewater treatment, Water Research, 33(17),3617-3629.

7. Exall K., Vanloon G, (2000) Using coagulants to remove organic matter, Journal AWWA, November 2000.

8. Perry and Green (1984), Chemical Engineers' Handbook, Sixth Edition, McGraw-Hill. p. 1612,16-13.

9. URL: www.gallochem.com/Gallotannin.htm.

10. Hsu P.H.,Rennie D.A.(1962) Reactions of phosphate in aluminum systems I.,Canadian Journal of Soil Science, 42,197-209.

11. Standard Methods for the Examination of Water and Wastewater (1998), $20^{\text {th }}$ ed., American Public Health Association/AWWA, Washington DC, USA. 
12. Huang C., Shiu H. (1996), Interaction between alum and organics in coagulation, Colloids and Surfaces A: Physicochemical and Engineering Aspects, 113, 155-163.

13. Sedlak R., Phosphorus and Nitrogen Removal from Municipal Wastewater, Principles and Practice, Second Edition, Lewis Publishers p. 95.

14. Gregor J., Noke C, Fenton E., (1997) Optimising Natural Organic Matter removal from low turbidity waters by controlled $\mathrm{pH}$ adjustment of aluminium coagulation, Water Research, 31(22), 2249-2958.

15. Baes, C.F.J., and Mesner, R.F. (1976) The Hydrolysis of Cations, John Wiley \& Sons, Inc., New York. 